\section{Лiтература}

1. Підаєв А. В. Болонський процес в Свропі. Що це таке і чи потрібний він Україні? Чи можлива інтеграція медичної освіти України в Свропейський освітній простір? / А. В. Підаєв, В. Г. Передерій. - Одеса : Одес. держ. ун-т, 2004. -190 c.

2. Волосовець О. П. Питання якості освіти у контексті впровадження засад Болонської декларації у вищій медичній школі / О. П. Волосовець // Досвід впровадження основних засад Болонського процесу в систему вищої медичної (фармацевтичної) освіти : матер. наук.-метод. конф. -Тернопіль, 2005. - С. 8-16.

3. Сучасний стан кадрової політики угалузі охорони здоров'я / 3. М. Митник, М. В. Банчук, І. І. Фещенко [та ін.] // Впровадження кредитно-модульної системи організацій навчального процесу у ВМ $(Ф) Н З$ України : результати, проблеми та перспективи : матер. навч.-наук. конф. - Тернопіль, 2010. - С. 3-5.

4. Педанов Ю. Ф. Практическое пособие по анатомии и физиологии человека / Ю. Ф. Педанов; под ред. А. И. Гоженко. - Одесса : Астропринт, 2008. - 52 с.

5. Педанов Ю. Ф. Практическое пособие по патологии / Ю. Ф. Педанов; под ред. А. И. Гоженко. -Одесса : Астропринт, 2009. -36 c.

6. Педанов Ю. Ф. Алгоритми засвоєння знань і практичних навичок у системі морфофункціональних наук у вузах I-II рівнів акредитації / Ю. Ф. Педанов, Р. Ф. Макулькін, А. І. Даниленко // Мед. освіта. - 2003. - № 1. - С. 18-21.

\title{
ПРАКТИЧНЕ ЗАНЯТТЯ 3 ФАРМАКОЛОГІї ЗАСОБІВ ІЗ СТИМУЛЮЮЧИМ ТИПОМ ДІї
}

\author{
В. А. Туманов, Н. О. Горчакова, О. Г. Тимченко, Г. М. Войтенко, І. С. Чекман, \\ І. М. Тимченко, Н. О. Юсько, І. Ю. Яковлєва
}

Київський медичний університет УАНМ, Національний медичний університет імені О. О. Богомольия, Національна медична академія післядипломної освіти імені П. Л. Шупика

\section{PRACTICAL LESSON ON DRUGS WITH STIMULATING TYPE OF ACTION}

\author{
V. A. Tumanov, N. O. Horchakova, O. H. Tymchenko, H. M. Voytenko, I. S. Chekman, \\ I. M. Tymchenko, N. O. Yusko, I. Yu. Yakovlieva \\ Kyiv Medical University UAFM, National Medical University by O. O. Bohomolets, \\ National Medical Academy of Post-Graduate Education by P. L. Shupyk
}

\begin{abstract}
Визначено групи препаратів, що тестують на занятті з фармакології засобів із стимулюючим типом дії.
It was determined the groups of drugs with stimulating action type that are tested at the lesson.
\end{abstract}

Вступ. Впровадження кредитно-модульної системи (КМС) у вищих медичних навчальних закладах має на меті підготовку кваліфікованих спеціалістів та створення системи освіти світового рівня. Навчання за КМС передбачає оволодіння конкретними практичними навичками, а кожне заняття включає питання вхідного і вихідного контролю. Ця система не є статичною, застиглою (хоча, головним чином, і трактується як метод перевірки знань), а удосконалюється з року в рік. На занятті, присвяченому фармакології препаратів із стимулюючим типом дії, за планом розбирається певний матеріал, що включає фармако- логію психомоторних стимуляторів, адаптогенів (психотоніків), ноотропних засобів, антидепресантів.

Основна частина. Труднощі засвоєння студентами фармакології лікарських засобів (ЛЗ), які переважно регулюють функції ЦНС (засоби для наркозу, антиконвульсанти, анальгетики, нормотиміки та інші групи), пов'язані зокрема із відсутністю у студентів базових знань 3 пропедевтики неврології і психіатрії, дефіцитом деяких спеціальних відомостей і понять 3 вищої нервової діяльності, нейрофізіології. Заради підвищення мотивації у студентів і продуктивності навчання викладач так чи інакше мусить проводити

(c) В. А. Туманов, Н. О. Горчакова, О. Г. Тимченко та ін. 
клінічні паралелі, використовуючи відповідні терміни, поняття, пояснюючи сутність клінічних феноменів; доречним, наприклад, є наведення у вельми стислому (та дещо спрощеному) вигляді нозологічної класифікації депресій, основних напрямків їх лікування, загальних принципів проведення тимоаналептичної терапії. Окрім надання визначень відповідним нейротропним (переважно центральної дії)/психотропним фармакологічним групам, пояснення (коментарів) щодоїх хімічних та фармакодинамічних класифікацій, важливо ще раз підкреслити умовність розподілу фармакологічних груп ЛЗ на такі, що виключно пригнічують або, навпаки, стимулюють ЦНС, зазначити наявність в межах більшості груп, що впливають на ЦНС (транквілізатори, нейролептики, антидепресанти, ноотропні засоби, адаптогени тощо) одночасно препаратів, у яких переважають ефекти або власне стимуляторів, або седатиків, або Л3 із так званим збалансованим типом дії. Треба також розтлумачити відмінність самих понять “седативна дія” та “стимулююча дія” (модальність, діапазон) для різних психотропних груп (наприклад для нейролептиків, транквілізаторів, седативних засобів, антидепресантів, ноотропів). Після розгляду основних аспектів механізму дії, загальної характеристики основної дії (в тому числі її розвитку в часі), найважливіших особливостей фармакокінетики, типових побічних ефектів, показань і протипоказань, небезпечної лікарської взаємодії (фармакобезпеки) для препаратів конкретної фармакологічної групи, доцільно навести приклади відмінностей спектрів і прояву клінічних ефектів в залежності від фармакодинамічних властивостей препаратів, продемонструвати стислу порівняльну характеристику двох-трьох основних (еталонних) препаратів кожної групи, вказати на дозозалежність терапевтичних ефектів, їх варіабельність, що пов' язана iз індивідуальними особливостями організму пацієнтів та особливостями етіопатогенезу (зокрема, налічується білыш ніж 20 біохімічних “різновидів" депресій); також не можна не назвати новітні ефективні препарати та не зазначити їх переваги. Взагалі, без привнесення елементів клініки, питань практичного застосування препаратів важко розраховувати на активну співпрацю із студентами, жвавий інтерес до теми, якісне засвоєння матеріалу. Важливі складові успішного опанування основними положеннями відповідної теми з фармакології такі: 1) сумлінна самостійна позааудиторна підготовка студентів до заняття, яка включає вивчення матеріалу за підручником та за допомогою рекомендованої літератури відповідно до переліку теоретичних питань методичної розробки до заняття, а також виконання письмової домашньої роботи (власноручнезаповнення таблиць протоколу у робочому зошиті: класифікації з номенклатурою ЛЗ, показаннями і протипоказаннями для них; визначення і порівняльна характеристика фармакологічних груп; розв' язання фармакологічних та фармакотерапевтичних задач; виконання завдань 3 рецептури (із зазначенням точної групової належності ЛЗ, докладною сигнатурою, конкретним показанням); задачі/алгоритми 3 невідкладної допомоги при медикаментозному отруєнні тощо); 2) проведення опитування студентів із обговоренням питань теми, що супроводжується поетапною демонстрацією фрагментів мультимедійної презентації-мікролекції, таблиць, колекції лікарських препаратів; 3) вихідне і заключне тестування; 4) індивідуальне розв' язання фармакологічних і фармакотерапевтичних задач, в тому числі за допомогою довідкової літератури; 5) використання деяких загальновідомих інтерактивних методів навчання (тобто елементів тренінгу). Викладач повинен побудувати заняття таким чином, щоб перевірити набуті знання за підрозділами, які входять до робочої навчальної програми і розбиралися студентами самостійно. Щоб зробити заняття більш цікавим, можна зупинитися при розборі фармакології психомоторних стимуляторів не тільки на фармакології кофеїну, який згадується в лекційному матеріалі і на практичному занятті, присвячених фармакології органів дихання. Великий інтерес викликає антиастенічний препарат, похідне тіаміну - енеріон. Антидепресанти зараз включають велику групу різних засобів, які хворі приймають тривалий час і які повинні мати, крім значної ефективності, малу токсичність. Цим вимогам відповідають лікарські засоби, які впливають на рецептори мелатоніну (мелітор), та препарати звіробою (деприм, геларіум гіперікум). Викладання фармакології вимагає знання класичних постулатів предмета, які були розроблені і надалі розробляються вченими України і світу. Студент повинен не тільки отримати факти, але й уміти застосовувати їх у практичній діяльності. Студентам всіх факультетів Київського медичного університету УАНМ, які поглиблено вивчають фармакогнозію та фітотерапію (за навчальною програмою), необхідно знати про антидепресанти із звіробою (деприм, геларіум гіперікум) тому, що екстракт трави звіробою протидіє порушенням нейротрансмітерної передачі, інгібує моноамінооксидазу та катехол-орто-метилтрансферазу, модулює секрецію інтерлейкіну-6. Важ- 